\title{
LANGUAGE USE AND IDENTITY AMONG MIGRANT ROMA
}

\author{
Hristo Kyuchukov \\ hkyuchukov@gmail.com \\ University of Silesia, Poland \\ Sava Samuilov \\ samuilov.sava@bbw-leipzig.de \\ Leipzig Vocational Training Establishment, Germany
}

Received May 4, 2019; Revised June 4, 2019; Accepted June 26, 2019

\begin{abstract}
The paper presents the issue of language use and identity among Muslim Roma youth from Bulgaria, living in Berlin, Germany. Interviews with a structured questionnaire on language use and identity was conducted with Bulgarian Muslim Roma living in Berlin, Germany. The results showed that, in order to be accepted by the German Turks, Bulgarian Muslim Roma youth change their language use and identity from Muslim Roma to a new identity - Bulgarian "Osmanli" Turks. The findings showed that the change of language and identity among young Roma in this study served as strategies for integration and acceptance in the German society.
\end{abstract}

Keywords: language use, ethnicity, identity, acculturation, Roma.

Кючуков Хрісто, Самуїлов Сава. Уживання мови та питання ідентичності серед ромів-мігрантів.

Стаття присвячена питанням використання мови та ідентичності серед ромівмусульманів, котрі проживають у Берліні, Німеччина. Результати показали, що для того, щоб бути прийнятими німецькими турками молоді роми- мусульмани змінюють свою мову в щоденній комунікації, а також ідентичність, та називають себе болгарськими османськими турками. Проведене дослідження демонструє, що зміна мови та ідентичності серед молоді ромів слугували стратегіями для інтеграції та прийняття в німецьке суспільство. Стратегії, які використовують молоді роми-мусульмани, емігруючи з Болгарії до Німеччини через дискримінацію та расизм у болгарському суспільстві, що спостерігається проти ромів та мусульман, відомі з наукових джерел серед інших мігрантів, а також в інших частинах світу, як стратегії прийняття в суспільство та успішної інтеграції.

Ключові слова: використання рідної мови, етнічність, ідентичність, акультурація, роми.

\section{Introduction}

After Bulgaria became a member of the European Union in 2007, Bulgarian Roma had the possibility of travelling freely in Europe, and to settle in other Western European countries. EU countries with large Turkish migrant communities such as Belgium, France and Germany became preferable destinations for the Bulgarian Muslim Roma. This is because they speak Turkish, and this language was useful in finding jobs and establishing relations with Turkish migrants in these countries.

The younger Bulgarian Muslim Roma living in Western European countries usually do not speak the Romani language and know very little about Roma history and Romani culture. They often identify themselves as Turks. In Bulgaria, the

(C) Kyuchukov, Hristo; Samuilov, Sava, 2019. This is an Open Access article distributed under the terms and conditions of the Creative Commons Attribution 4.0 International Licence (http://creativecommons.org/ licenses/by/4.0).

East European Journal of Psycholinguistics, 6(1), 47-57. https://doi.org/10.5281/zenodo.3377511 
Turkish minority and the Turkish language can have higher prestige in comparison with Romani language and Roma identity (Kyuchukov, 2007). Rather than identify themselves as Bulgarian Muslims, and as immigrants in Western European, these youth have tended to identify themselves as Turks or Ottoman Turks (Osmanll Turkleri). The identity of millet (from tr. milliet - nation) which is equal to Muslim Roma used in Bulgaria, is not used any more. They use the Turkish identity and speak Turkish, but their Turkish is different from the Turkish spoken by the Turkish migrants (in Germany) and in order to avoid any discrimination by migrant Turks they usually explain that they belong to the Ottoman Turks (Kyuchukov, 2016).

Like many immigrants, Muslim Roma youth in Germany are aimed at succeeding in Germany. Navigating languages and identity questions are central to the adaptation of the youth considered in this chapter and as Dimitrova and Ferrer Wreder (2017) wrote "the Roma youth with multiple or flexible ethnic identities are more likely to be successful in school and in society" (p. 326). For Roma youth in the study learning a Berlin variation of Turkish and adapting to the local rules of the Turkish community are a guarantee of well-being and success in the German society.

K. Brizic (2006) reports about a similar phenomenon among immigrant children in Austria, where there are differences between the L1/L2 acquisition by children from Turkey and former Yugoslavia. The article focuses on the countries of origin, taking into account particularly their policies on (minority) language(s) and education, integrating approaches from socio- and psycholinguistics as well as language attrition studies, sociology and pedagogy.

Keeping in mind the situation of Bulgarian Muslim Roma migrant youth in Berlin, and their desire to be successful in Germany, this article addresses the following research question:

What are the problems of language use and identity among Bulgarian Muslim Roma youth in Berlin, Germany?

This question will be addressed taking as our point of departure, the ethnic background, language and communication skills of the Bulgarian Muslim Roma migrant youth.

\subsection{Clarification of Key Terms}

In this section, the terms ethnicity and identity change and their connection to the language use are discussed. The changes of the ethnicity and identity are parts of the acculturation process and the language use plays an important role in it. It is also important to note that adolescence concerns identity formation and changes in the structure of personality in the context of the surrounding world (Erikson, 1964). Main questions of the identity search are: what are we, what want we to be, and what others expect from us?

\section{Ethnicity}

Ethnicity is a term used for a group of people based on perceptions of shared social experience or one's ancestors' experiences (Peoples \& Bailey, 2010). For example, "members of the ethnic group see themselves as sharing cultural traditions 
and history that distinguish them from other groups. Ethnic group identity has a strong psychological or emotional component that divides the people of the world into opposing categories of "us" and "them" (Peoples \& Bailey, 2010, p. 389).

According to Fishman (1998), language is the main indicator of the ethnicity. The link between the language and ethnicity depends on the context, and is also rooted in social and/or historical circumstances. The processes of globalization and mobility however, also influence language and ethnicity. Fishman (1998) reported also that among small ethnic groups such a phenomenon as changing from one ethnicity to another bigger nationality is common.

\section{Identity}

According to Rovira (2008) "identity, simply stated, is who you are; individuality; the condition of being a certain person. In the social sciences, identity is defined as the way that individuals label themselves as members of a group; in psychology, it refers to an individuals' self-esteem or self-image" (p. 65-66). Language is important to identity, the same person in one situation can use a dialect of a language and have an identity connected to that dialect, and in another situation, can use another dialect of the same language and have a totally different identity. The change of the identity can be individually experienced, but very often can be a collective action.

\section{Language}

Language is an instrument to express culture. Rovira (2008, p. 66) stated that "...language is a fundamental aspect of cultural identity. It is the means by which we convey our innermost self from generation to generation. It is through language that we transmit and express our culture and its values". Language and identity are closely related and, in many societies, and language is a sign of the social, caste, educational and cultural groups to which a person may belong to.

\section{Acculturation}

Berry (1997, p. 6) stated that "The concept of acculturation is employed to refer to the cultural changes resulting from these group encounters, while the concept of psychological acculturation and adaptation are employed to refer to the psychological changes and eventual outcomes that occur as a result of individuals experiencing acculturation. Three interrelated aspects of adaptation are identified: psychological, sociocultural and economic". Organista, Marin, and Chun (2010) presented acculturation as a more complex phenomenon that considers at least two cultural dimensions where, an individual may retain some aspects of the culture of origin and also learn and favor aspects of the new culture. This more complex understanding of acculturation is often perceived as promoting a society characterized by individuals who are comfortable in various cultural settings (Padilla and Perez, 2003).

In different European countries where Roma groups live, in order to avoid everyday discrimination, some may take on different identities and may assimilate into the mainstream society. Kivisto (2013) has shown that in Europe, negative attitudes, open discrimination, and the exclusion of migrants are increasing, and 
these trends and experiences are applicable for Roma migrants as well. Kivisto (2013, p. 127) described the situation in this way:

"...it is often difficult to disentangle the sources of anti-immigrant animus. On the one hand, immigrants qua immigrants are often the object of hostility. They can be seen as competitive threats and economic burdens to the receiving society, as well as being in various ways perceived to be culturally 'different' in negative terms. Thus, findings from the Eurobarometer in the early years of the twenty-first century found that one in five Europeans in 15 countries surveyed believed that their nation should enact repatriation policies for legal migrants, while four out of ten interviewees expressed opposition to the granting of civil rights to legal migrants."

From another perspective, a study conducted in Britain and France showed that the Roma were viewed as being on the bottom of the hierarchy in terms of prejudices in those societies. The prejudices towards Roma can be greater than antiMuslim prejudices (Bleich, 2009). The situation in Berlin is not different. Visiting the Berlin schools one can see that migrant children and youth (Turks and Arabs) have negative attitude towards Roma children and youth from Bulgaria and Romania. Very often they are victims of verbal attacks and bullying and in this sense to "be a Turk from Bulgaria" maybe perceived to be less dangerous and more prestigious, than to be a Roma.

\subsection{Language, Social Identity, Acculturation and the Study Context}

The key terms (i.e., ethnicity, identity, language, and acculturation) play an important role in the process of social identity in a multicultural and multilingual context. According to Tabouret-Keller (1998), the collective change of identity can be a guarantee for a higher social status and possibly living better in a new society. "Accommodation theory" posits that the shift of speech styles is done with the aim of social integration and this phenomenon is very typical in multilingual communities (Giles, 1984 as cited in Tabouret-Keller, 1998).

Language, ethnicity and identity play important role in accommodation theory. From one side, language and ethnicity are connected, but from other side, there is also a tight connection between the language and identity. Language is the most important criteria of the accommodation theory and it guarantees the adaptation of the person in a new context and to a new situation.

Muslim Roma youth from Bulgaria living in Berlin are typically multilingual. In addition to speaking Turkish and Bulgarian, they may also speak some German. At school, they are taught English as well, and some of them had learned some Russian in Bulgaria before coming to Germany. Their fluency in these languages varies, but often times they have to negotiate through a myriad of languages; and each of these languages may impact their identity. The Muslim Roma community in Berlin, Germany, is well established and the Roma have good connections among themselves. They tend to stick together as a social group, consistent with what Tajfel and Turner described "The individuals will not interact as individuals, on the 
basis of their individual characteristics, but as members of their group" (1986, p. 10). In the Roma community, the youth has a new role. To begin with, they receive German school education as well as learn from the local streets, the new local variety of Turkish spoken in Berlin. Some of the youth also attend Turkish language lessons at school, a dialect of Turkish which the Bulgarian Muslim Roma considers to be more prestigious than the Bulgarian Turkish variety. Soon upon arrival in Germany, many of the children and the youth identify themselves as Bulgarians. However, after improving their Turkish, they change their identification to that of Turks from Bulgaria. Because of their language skills, Roma parents often call on the help of their children as translators/interpreters, when they have to communicate with German official institutions.

For Ochs (1993) the term "social identity" is a "cover term for a range of social personae, including social status, roles, positions, relationships, and institutional and other relevant community identifies one may attempt to claim or assign in the course of social life" (p. 288). The relation between language and social identity is very tight as well. Bailey (2001) analyzed how, when, and why individuals identify as members of particular groups. Conducting research among young Dominican Americans, the author showed how language was used to enact a specifically non White identity, adapting the Afro-American Vernacular; or to linguistically claim a distinct "non-Black" Spanish/Dominican identity; or to illustrate the way in which Dominican migrants situationally highlight boundaries among themselves. Language was functioning as an emblem of identity. According to Fought (2006) "there are number of types of linguistic resources in multiethnic communities for speakers to use in indexing the ethnic identity: 1.) a heritage language; 2.) codeswitching; 3.) specific linguistic features; 4.) suprasegmental features; 5.) discourse features; 6.) using a borrowed variety" (p. 21-22).

In another study, Kyuchukov (2016) observed that speaking Turkish, the Muslim Roma youth code-switched to Bulgarian and German, as well as used specific linguistic and discourse features. Very often among themselves, they would speak either Bulgarian or Bulgarian dialect of Turkish; but when among the Turkish migrants form Turkey living in Berlin, they are likely to immediately use another dialect of Turkish, namely the Berlin Turkish. Thus, the Muslim Roma community living in Berlin shows many signs of assimilation into the wider society. In a unidirectional model of acculturation in which "the cultural change occurs in one direction - people move away from their culture of origin and toward the dominant group during resettlement in a new country" (Organista, Marin, \& Chun, 2010, p. 103). It may also be the case, that Muslim Roma youth living in Berlin do not learn much of the majority language (i.e.6 German) and culture. Instead, they are interested in acquiring the culture of another migrant group in Germany, namely, Turk immigrants who arrived in the 1960s and 1970s to Germany.

The primary goal of young Muslim Roma in Berlin is to be well received in the Turkish community and to prosper in the German society. For them, it is clear that well-being in German society, involves becoming integrated with the Turkish migrant community, who have succeeded in gaining respect, cultural, linguistic and 
human rights in the German society. Children and students of Muslim Roma who attend primary and secondary schools learn Turkish as mother tongue in classes provided by the schools, attend cultural or sport clubs run by Turks and adapt to Turkish culture and value system of Turkish minority in Berlin. This is the way, they think that they will be successful and have prosperity in the wider German society.

The overview of the literature in application to the case of young Muslim Roma in Berlin shows that the issues of language and identity change are not new in social psychology and in sociolinguistics. Small and isolated ethnic minority groups are often targets for discrimination and rejection in a variety of societies. Human beings try to find ways to be accepted and appreciated in societies and the cases described here have been observed in other contexts, such as in North America, Australia and Europe. Well-being is a normal human desire and young Roma in a new context act and behave no differently from any other human beings. They simply would like to be accepted and to find their place in the society. In the literature, one can find many cases of young Black or Latino Americans, young Arabs in France and Belgium, young Turks in Europe, who behave in the same way - going through the processes of acculturation in order to be integrated in a wider society. The young Muslim Roma in this study are not an exception to this case.

\section{Methods}

Here, we present a description of results from a study among Bulgarian Muslim Roma youth. The focus of the study was to explore how these youth viewed themselves, and their views on identity and language use in their lives.

Study participants were either enrolled in schools in Berlin or had graduated from a Bulgarian institution and migrated to Berlin in search of a job. Here, they face a new reality: a large Turkish speaking community from Turkey and will have to navigate how to integrate into the German society often through the Turkish community. Participants were 17 adolescent boys and 12 girls between 16-22 years old. They were interviewed using a structured questionnaire in informal settings. Based on the participants' responses, the sample maybe viewed as consisting of two groups. The first group comprised of participants who were born in Germany or came to Germany at very young age. This group reported being interested getting higher education, reported motivation to study German, to get a profession, and they did not appear to be isolated from the German society. They reported contacts with Germans, Bulgarians and Turks. This was a smaller group in the overall sample. The other group of respondents came to Berlin in the course of the last three to four years. They reported more isolation, having contacts only with relatives, and Bulgarians and very few contacts with Turks. They had little to no desire to learn German, and reported conflicts the law including criminality or prostitution.

The questionnaire contained 19 questions divided into three parts dealing with social-demographic information, identity, language use, and integration. The 
participants' responses to the questions were open ended and their answers were written down on a form. For example:

What language do you speak with: a) your parents, b) your brothers and sisters, c) your relatives, d) your friends, e) someone from Bulgaria on the street/ shop, f) other people

Identity and language were assessed using the same items as Broeder and Extra's (1995) survey. The items focused on:

language variety: Which language(s) is/are used in your home?,

language proficiency: Can you understand/speak/ read/write this language?,

language choice: Do you speak this language with your mother/father/ elder brothers $(s)$ or sister $(s) /$ younger brother $(s)$ or sister $(s)$ ?,

language dominance: Which language do you speak best?,

language preference: Which language do you like to speak most?

The qualitative data were coded with the codes 1 and 0 . For positive answers, the code 1 was given, and for negative ones - the code 0 was given.

\section{Results}

In both groups of youth, Turkish was the mother tongue. Only $6 \%$ of participants spoke some Romani at home. All of them spoke and understood Bulgarian, but only $12 \%$ used it in their everyday communication. Bulgarian was rarely used, because the social contact with ethnic Bulgarian speakers was limited. Most of the Muslim Roma youth reported using Turkish (44\%) or Turkish and Bulgarian $(38 \%)$ in their homes. They did not report speaking German at home.

Herein their language preferences, there was not so much diversity. Many preferred to speak the Berlin variety of Turkish, which they considered as "standard" Turkish (88\%) and others (mainly the ones who were born in Berlin and came very young) preferred to speak German (12\%). There were no preferences towards Bulgarian and Romani language.

In Bulgaria, all respondents identified themselves as millet, which is the other name of Muslim Roma. In Germany, in communication with migrant Turks from Turkey, they reported identifying themselves as Turks/Bulgarian Turks or "citizens of old Ottoman Empire" which is equal to Turkish. Only 3\% reported identifying as Roma. Almost all of them identify themselves as Turks (when communicating with migrant Turks from Turkey) and as Bulgarians (when communicating with Germans). In Bulgaria, they all used Turkish as their mother tongue at home, but would not or could not use it in public. In Berlin, they would use Turkish in public places, such as in shops, restaurants, schools. None of them identify themselves as Germans or Bulgarians in communication with Roma, Turks or Bulgarians from Bulgaria. The results are shown in Figure 1.

Here are some of the reasons given by participants regarding their willingness to identify as Turks. 


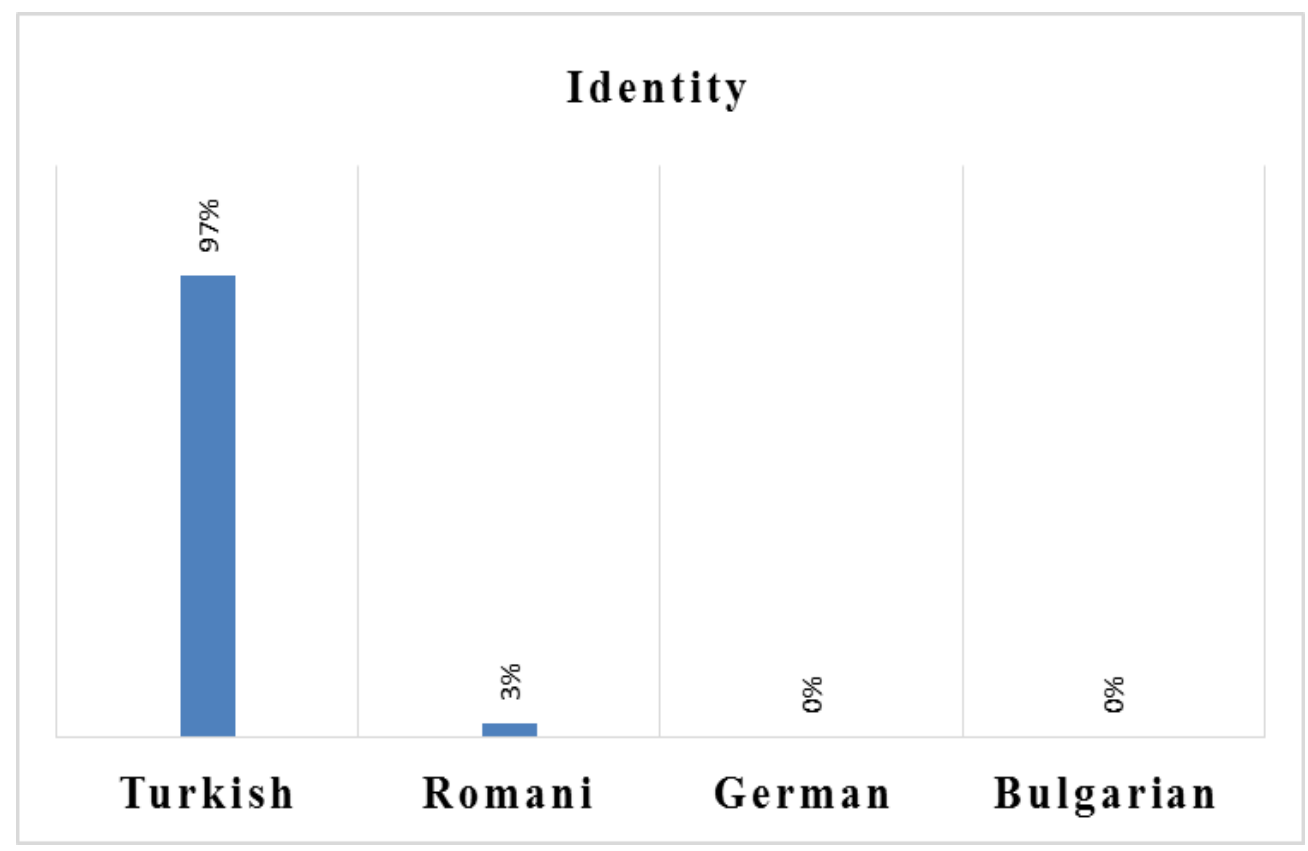

Figure 1. Self-Identification of Bulgarian Muslim Roma Youth in Berlin

Participants stated that: "to be a Roma or Turk in Bulgaria means that you are not a human being"; "no one wants me in Bulgaria"; "I am treated differently in Bulgaria". The Bulgarian society, last decade or so, has shown that otherness and minorities, particularly Roma, are not accepted. The open discrimination in everyday life turns to be a norm. Opposite to the Bulgarian situation many reported that to be Roma or Turkish in Germany means: "I feel not discriminated"; "I am accepted as I am".

Most of the participants (92\%) reported that they thought that the Turkish language facilitates their integration into the German society, and $8 \%$ reported that they thought German and English would facilitate their integration into German society.

Although the Muslim Roma youth can freely identify as Roma in Germany, they prefer to identify themselves as Turks, because of the Turkish language and Turkish ethnicity has some prestige in Germany. Antigypsyism takes a different form in Germany than in Bulgaria, but the negative attitudes towards Roma nevertheless still exist. This issue becomes clearer when one considers two questions regarding the future of Romani. One of the questions was in connection with the desire of the young people to have Romani language as a subject in schools similar to Arabic and Turkish in German educational system. Overwhelming majority of the participants (89\%) were negative towards this proposition. Only $11 \%$ thought it was important to have Romani as a subject in the German educational system. The other question was about wanting their children to learn Romani and to identify as Roma. Here too, nearly all the participants $(97 \%)$ were negative to the idea. Only 3\% from the Muslim Roma youth thought that it is important for the future of Romani language that when they have families and have children to speak Romani in their households. 
In answering the research question stated above we contend that for Bulgarian Muslim Roma youth in Berlin, the integration into German society is considered as a positive development, however for the time being they see it possible only through the Turkish language and Turkish identity. In their opinion, the Berlin dialect of Turkish is more valued than the Bulgarian dialect of Turkish. The children and youth try to learn the Berlin Turkish, although they code-switch between Bulgarian Turkish and Berlin Turkish variety (Giray, 2015) and surely future generations will be much better in Turkish spoken in Berlin and they will see themselves as having a Turkish identity (Marushiakova and Popov, 2004)

\section{Discussion}

The Muslim Roma youth coming from Bulgaria and being raised in a society where the attitudes towards minorities are extremely negative have experienced the so called "Matthew effect" (Merton, 1968), where the gap between the majority and minorities becomes bigger and bigger. In Bulgarian, the minorities get more and more isolated and without any power and positions in political life. Bulgarians on the other hand get more and more aggressive towards minorities and exclude the minorities (including high educated and highly qualified minority members) from the social and political life. Having all the negative experiences from Bulgaria and being in a new country where one of the minority groups has higher prestige and is well integrated in the society, the process of acculturation among the Muslim Roma youth is a result from the desire to overcome the "Matthew effect" - the gap between the minority and majority.

Changing language and identity is one of the strategies which can help to overcome the existing gap. This is a phenomenon well described in social psychology (Bailey, 2001). The grounds of this phenomenon are different. One is psychological: the low self-esteem of a group of people belonging to a minority group. A second one is economical: the desire on the part of minority group to be integrated in the society (acculturation) in order to enhance job employment opportunities. The third one is political: members of a minority group avoiding direct racism and discrimination. The fourth is religious one, when the members of a group are scared about their lives and future.

From sociolinguistic point of view, Turkish and German languages for Bulgarian Muslim Roma youth in Berlin are "Ausbau" and "Abstand" languages, as described by Trudgill (1992). Abstand in German means "distance" and Ausbau is "extension". For Muslim Roma youth, the language which gives them extension in the German society is Turkish. German is a language which is one of distance. Most probably, the children and grandchildren of these youth will speak better German. For Muslim Roma youth from Bulgaria living in Berlin, the integration in the German society goes through Turkish community, learning a "new" Turkish dialect and having a "new" identity - from Ottoman Turks to Turks. This is one of the strategies of prosperity and well-being in the new context - just a basic human desire. 


\section{Conclusions}

Changing of one's language, ethnicity and identity are strategies used in context of the aforementioned study and may have relevance to other highly discriminated against minorities and/or numerically smaller ethnic/social groups. The six Cs of competence, confidence, connection, character, caring and contribution (Lerner et al., 2005; Lerner, Dowling \& Anderson, 2003) in the case of Muslim Roma in Berlin is possible, but may only be achieved through the Turkish identity and language. In the German society, the forms of anti-gypsyism are increasing. The young Muslim Roma in Bulgaria witnessing the forms of antigypsyism towards other Roma groups from Romania, Macedonia, Bosnia and Serbia, use their religion and knowledge of Turkish to "accommodate" to the German society, respectively to have a better life in the society. The tight connections with the Turkish community gives a possibility to young Muslim Roma to have confidence, to show their competence, to create connection, to develop their character, to show care and love to family members and to contribute in the society as a whole. The long term consequences of this accommodation strategy are yet to be known for youth in this study. However, the use of this strategy was clearly relevant in this sample.

This study has several limitations such as a non-representative study sample, and it could have been enriched by the use of other methods. Despite these limitations, the study findings provide a good base to continue research with other groups of young Roma in different European contexts. The most important question is how to support a context in which young Roma can be proud of their ethnicity and language and also have success in the wider society, so that future generations can avoid being completed assimilated into the mainstream culture at the cost of their heritage and identity. The number of initiatives taken by institutions such as Council of Europe and European Commission aiming and focusing on the educational and professional development of young Roma, do not pay enough attention to the issues of identity and Romani language use, and the context that young Roma must navigate in order to thrive.

\section{References}

Bailey, B. (2001). The language of multiple identities among Dominican Americans. Journal of Linguistic Anthropology, 10(2), 190-223.

Berry, J. (1997). Immigration, acculturation and adaptation. Applied Psychology: An International Review, 46, 5-36.

Bleich, E. (2009). Where do Muslims Stand on Ethno-Racial Hierarchies in Britain and France? Evidence from Public Opinion Surveys, 1998-2008; 43, 379-400.

Brizic, K. (2006). The secret life of a languages. Origin-specific differences in L1/L2 acquisition by immigrant children. International Journal of Applied Linguistics, 16(3), 339-362.

Broeder, P. \& Extra, G. (1995). Ethnic identity and community languages in the Netherlands In: Sociolinguistica - International Yearbook of European Sociolinguistics/ Internationales Jahrbuch für europäische Soziolinguistik, 9, 96-112.

Dimitrova, R., Ferrer-Wreder, L. (2017). Positive Youth Development of Roma Ethnic minority Across Europe. In: Handbook on positive development of minority children and youth (pp. 307-320). N. Cabrera \& B. Leyendeker, (Eds.). New York: Springer

Erikson, E. (1964). Childhood and Society. New York: W. W. Norton \& Company. 
Fishman, J. (1998). Language and ethnicity: The view from within. In: The Handbook of Sociolinguistics. (pp. 327-343). F. Coulmas (Ed.). Oxford: Blackwell.

Fought, C. (2006). Language and ethnicity. Cambridge: Cambridge University Press.

Giles, H. (ed.) (1984). The Dynamics of speech accommodation. International Journal of Sociology of Language, 46, 1-155

Giray, B. (2015). Code-switching among Bulgarian Muslim Roma in Berlin. In: Ankara Papers in Turkish and Turkic Linguistics. (pp. 420-430). D. Zeyrek, C.S. Șimșek, U. Ataș and J. Rehbein (Eds.). Wiessbaden: Harrassowitz Verlag.

Kivisto, P. (2013). (Mis)Reading Muslims and multiculturalism. Social Inclusion, 1, 126-135.

Kyuchukov, H. (2016). The Turkish in Berlin spoken by Bulgarian Muslim Roma. Ural-Altaic Studies, 22, 7-12.

Kyuchukov, H. (2007). Turkish and Roma children learning Bulgarian. Veliko Tarnovo: Faber.

Larson, R. W. (2000). Toward a psychology of positive youth development. American Psychologist, 55, 170-183.

Lerner, R. Et al. (2005) Positive youth development. A view of the issues. Journal of Early Adolescence, 25(1), 10-16.

Lerner, R., Dowling, E., Anderson, P. (2003) Positive youth development: Thriving as the basis of personhood and civil society. Applied Developmental Science, 7(3), 172-180.

Marushiakova, E. \& Popov, V. (2004). Muslim Minorities in Bulgaria. In: Migration and Political Intervention: Diasporas in Transition Countries. (pp. 18-32). Blaschke, J. (Ed.). Berlin: Parabolis.

Merton, R. (1968). The Matthew effect in Science. Science, 159(3810), 56-63.

Ochs, E. (1993). Constructing social identity: a language socialization perspective. Research on Language and Social Interaction, 26, 287-306.

Organista, P. B, Marin, G., Chun, K. M. (2010). The psychology of ethnic groups in United States. London: SAGE Publication.

Padilla, A., Perez, W. (2003). Acculturation, social identity and social cognition: A new Perspective. Hispanic Journal of Behavioral Sciences, 25, 35-55.

Peoples, J., Bailey, G. (2010). Humanity: An Introduction to Cultural Anthropology (9th ed.). Belmont, CA: Wadsworth Cengage learning.

Rovira, L. (2008). The relationship between language and identity. The use of the home language as a human right of the immigrant. Revista Interdisciplinar da Mobilidade Humana, XVI (31), 63-81.

Tajfel, H. Turner, J.C. (1986). The social identity theory of intergroup behavior. In: Psychology of Intergroup Relations (pp. 7-24). Worchel, S. \& Austin, W. G. (Eds.). Chicago: Nelson-Hall.

Tabouret-Keller, A. (1998). Language and identity. In: The Handbook of Sociolinguistics. (pp. 315-326). F. Coulmas (Ed.). Oxford: Blackwell.

Trudgill, P. (1992). Ausbau sociolinguistics and the perception of language status in contemporary Europe. International Journal of Applied Linguistics, 2, 167-178. 